\title{
Pelatihan Bahasa Inggris Bagi Anak Usia Dini di Daerah Terpencil Kecamatan Pademawu Pamekasan
}

\author{
Muhammad Amiruddin, Ukhti Raudhatul Jannah* \\ Fakultas Keguruan dan Ilmu Pendidikan, Universitas Madura, Madura, Indonesia \\ *Coresponding Author: ukhti_math@unira.ac.id \\ Dikirim: 12-06-2021 ; Direvisi: 14-06-2021 ; Diterima: 14-06-2021
}

\begin{abstract}
Abstrak: Pengabdian Kepada Masyarakat ini bertujuan untuk memberikan pelatihan bahasa Inggris bagi anak usia dini di daerah terpencil Kecamatan Pademawu Pamekasan. Tahapantahapan dalam kegiatan ini adalah (1) pemberian materi bahasa Inggris yang dilakukan dengan mengenalkan objek yang dapat dilihat, diraba, dan dirasa oleh anak usia dini di daerah terpencil Kec. Pademawu Pamekasan, (2) pendampingan bahasa Inggris dengan memanipulasi aktivitas untuk menguatkan input bahasa Inggris, (3) Evaluasi kegiatan yang dilakukan dengan meminta respon respon dan saran terhadap kebermanfaan dan keberlanjutan kegiatan PKM. Kegiatan ini dilakukan untuk membantu dan mengenalkan bahasa Inggris bagi anak usia dini di daerah terpencil Kec. Pademawu Pamekasan sehingga mereka memiliki ketertarikan terhadap bahasa Inggris dan merubah presepsi negatif terhadapa bahasa Inggris dan meningkatkan identitas social masyarakat di daerah terpencil Kec. Pademawu Pamekasan.Luaran yang akan dihasilkan dalam pengabdian kepada masyarakat ini adalah mampu mengujarkan ujaran bahasa Inggris secara lisan.
\end{abstract}

Kata Kunci: Anak usia dini; daerah terpencil; bahasa Inggris

Abstract: This community service aims to provide English language training for early childhood in remote area of Pademawu Pamekasan District. The stages offer some activities those are (1) providing English material which is carried out by introducing objects that can be seen, touched, and felt by early childhood in remote areas of Pademawu Pamekasan, (2) manipulating activities to strengthen English input, and (3) Evaluating activities carried out by asking for responses and suggestions on the effectiveness and sustainability of PKM activities. This activity is carried out to assist and introduce English to early childhood in remote areas of Pademawu Pamekasan so that they have an interest in English and change negative perceptions of English and improve the social identity of people in remote areas of Pademawu Pamekasan. The output that will be generated in this community service is being able to pronounce English utterances orally.

Keywords: Early childhood; remote area; English

\section{PENDAHULUAN}

Kecamatan Pademawu merupakan salah satu kecamatan yang ada di Kabupaten Pamekasan. Kec. Pademawu juga merupakan kecamatan yang luas dibanding dengan kecamatan yang lain yang ada di Kabupaten Pamekasan. Tidak semua daerah di wilayah Kecamatan Pademawu memiliki kemajuan dalam bidang pendidikan dan sarana umum, sebagian dari wilayah yang dimiliki masih dalam kategori tertinggal atau terpencil yang mana beberapa wilayah di Kecamatan Pademawu memiliki akses jalan yang rusak dan setapak. Siswa sekolah dasar khususnya di dusun Kotambek Desa Tanjung Pademawu Pamekasan masih memiliki kesulitan, harus menempuh jarak dengan melewati jalan yang rusak serta becek pada musim penghujan. Masih banyak diantara mereka pergi kesekolah dengan 
menggunakan sandal japit dan bahkan tanpa alas kaki. Berdasarkan observasi awal diketahui bahwa siswa sekolah dasar di wilayah ini ketika waktu istirahat pergi ke pinggir pantai untuk mencari kerang dan banyak diantara siswa yang tidak kembali ke kelas ketika jam setelah istirahat tiba, mereka memiliki ketertarikan yang sangat minim untuk belajar dan mempelajari keterangan guru terlebih khususnya bahasa Inggris. Usia siswa di masa sekolah dasar merupakan masa yang bagus untuk memperoleh input dalam pembelajaran dan menerima pelajaran dari guru.

Usia dini merupakan golden age bagi pembelajar memperoleh input dalam pemerolehan dan pembelajaran bahasa Inggris. Dimasa ini, anak lebih cepat memperoleh masukan atau input dalam pemerolehan dan pembelajaran bahasa Inggris. Krashen (2009) dalam penelitiannya menyatakan bahwa anak yang tergolong golden age memiliki kecepatan dalam phonetic dan phonology. Anak usia dini dapat memperoleh input dengan cepat dalam pembelajarn bahasa Inggris. Penguasaan bahasa Inggris khususnya bagi generasi milenial penting dimiliki untuk mempersiapkan diri menghadapi perkembangan tekhnologi dan kemajuan zaman.

Bahasa Inggris akan mudah dipahami oleh anak usia dini di daerah terpencil Kec. Pademawu Pamekasan apabila guru dan trainers mampu menciptakan dan memanipulasi aktifitas dan kondisi pembelajaran yang efektif, sehingga mereka dapat melatih dan membiasakan diri menggunakan bahasa Inggris. Trainers merupakan fasilitator dan agent of change bagi siswa. Trainers di tuntut untuk memiliki kedekatan dengan siswa baik kedekatan secara sosial dan psikologis dengan siswa sehingga mudah bagi pembelajar bahasa khususnya anak usia dini memperoleh input (Fang, 2010). Amiruddin (2018) menyatakan bahwa kedekatan antara guru dan siswa mampu meningkatkan motivasi siswa dan mengurangi tingkat kecemasan siswa dalam pembelajaran bahasa Inggris. Amiruddin dan Suparti (2018) juga menambahkan bahwa tingkat anxiety pemebelajar bahasa berpengaruh terhadap capaian mereka. Mereka harus mampu melihat keinginan peserta dalam proses pembelajaran. Ini dapat membantu mereka berkomunikasi dengan bahasa Inggris. Perhatian yang diberikan guru atau trainers kepada siswa dapat memotivasi siswa berkomunikasi dengan bahasa Inggris, baik guru maupun siswa dapat saling memberi dan menerima informasi.

Pengenalan dan penguasaan bahasa Inggris bagi anak usia dini di daerah terpencil Kecamatan Pademawu Pamekasan penting untuk dimiliki untuk mempersiapkan diri menghadapi perkembangan zaman dan teknologi. Penguasaan bahasa Inggris juga dapat meningkatkan identitas sosial mereka. Dengan demikian, penting untuk dilakukan pelatihan bahasa Inggris bagi anak usia dini di daerah terpencil Kecamatan Pademawu Pamekasan.

\section{METODE PELAKSANAAN KEGIATAN}

Metode pelaksanaan dalam melaksanakan solusi yang ditawarkan untuk mengatasi permasalahan adalah sebagai berikut. Tahapan awal dari kegiatan ini adalah planning. Pada tahapan ini akan dilakukan pengamatan tentang need analysis terhadap situasi daerah terpencil di Kecamatan Pademawu Pamekasan. 

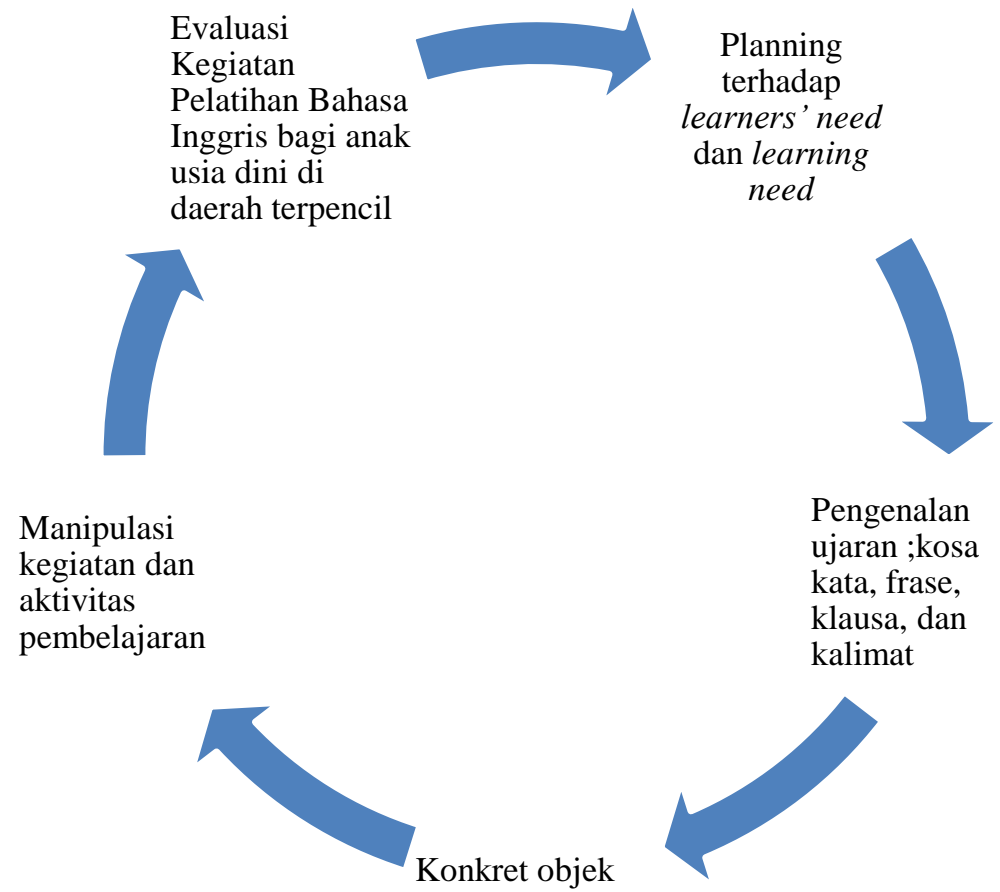

Pengenalan ujaran ;kosa kata, frase, klausa, dan kalimat

Gambar 1. Tahapan pengamatan tentang need analysis

Pengabdian kepada masyarakat ini dilakukan dengan beberapatahapan yaitu (1) tahapan pertama adalah dengan melakukan need analisis yang meliputi learners' needs dan leraning needs anak usia dini di daerah terpencil Kecamatan Pademawu Pamekasan, (2) tahapan kedua adalah melakukan pelatihan bahasa Inggris dengan mengenalkan kosakata, prahse, klausa, kalimat serta ujaran bahasa Inggris terhadapa objek yang dapat dilihat, diraba, dan dirasa oleh anak usia dini di daerah terpencil Kec. Pademawu Pamekasan; melakukan manipulasi aktifitas dalam pembelajaran, dan (3) tahapan ketiga adalah evaluasi kegiatan yang dilakukan dengan meminta respon dan saran untuk keberlanjutan kegiatan ini serta manfaat dari kegiatan PKM yang telah dilakukan. Hal ini dijadikan sebagai bahan kajian bagi tim PKM dalam rangka penyebarluasan pentingnya kemampuan bahasa Inggris dalam era globalisasi khususnya anak usia dini.

\section{IMPLEMENTASI KEGIATAN DAN PEMBAHASAN}

PKM pelatihan bahasa Inggris bagi anak usia dini di daerah terpencil Kecamatan Pademawu Pamekasan memiliki beberapa tahapan pelaksanaan. Tabel 1 menjelaskan tentang pelaksanaan dalam kegiatan PKM.

Tabel 1. Tahapan Kegiatan PKM

\begin{tabular}{cl}
\hline NO & \multicolumn{1}{c}{ Tahapan Kegiatan PKM } \\
\hline 1 & $\begin{array}{l}\text { Pembukaan PKM- pelatihan bahasa inggris bagi anak usia dini di daerah terpencil } \\
\text { kecamatan pademawu pamekasan }\end{array}$ \\
2 & $\begin{array}{l}\text { Penyelenggaraan PKM- pelatihan bahasa inggris bagi anak usia dini di daerah } \\
\text { terpencil kecamatan pademawu pamekasan }\end{array}$ \\
3 & $\begin{array}{l}\text { Penutupan PKM- pelatihan bahasa inggris bagi anak usia dini di daerah terpencil } \\
\text { kecamatan pademawu pamekasan }\end{array}$
\end{tabular}


PKM dimulai dengan paparan pentingnya bahasa Inggris di era milenial bagi anak usia dini dan pemberian materi bahasa Inggris yang bersifat konkret objek serta bahasa Inggris dasar yang dapat memudahkan anak usia dini memahami dengan mudah. Materi yang diberikan dalam kegiatan PKM adalah materi yang bersifat routine and pattern yang berupa kosakata keseharian dan konkrit bagi anak usia dini. Kegiatan ini dilaksanakan pada bulan Agustus 2020. Anak usia dini diberikan pelatihan bahasa Inggris seminggu sekali selama bulan Agustus 2020 dengan pemberian vocabularies untuk mengenalkan anak usia dini. Pada setiappertemuan, mereka selain diberikan kosa kata baru, juga diberikan kesempatan untuk menirukan pengucapan kosa kata tersebut dikombinasikan dengan permainan yang dapat meningkatkan motivasi mereka.

Pelaksanan kegiatan ini dilakukan oleh tim pengabdian dengan pokok bahasan yang disampaikan mengenai:

1. Penyampaian materi yang meliputi pentingnya dan manfaat bahasa Inggris dalam kehidupan di era melinial.

2. Penjelasan tentang pskiologis anak usia dini dalam pembelajaran bahasa Inggris.

3. Penjelasan tentang dunia anak usia dini

4. Pengajaran bahasa Inggris anak usia dini yang disesuaikan dengan lingkungan sekitar dan karakteristik siswa untuk menciptakan proses belajar mengajar yang active learning sehingga pembelajaran bersifat student oriented.

5. Tanya jawab dengan peserta PKM terkait dengan materi yang disampaikan dalam pembelajaran bahasa Inggris.

Dari kegiatan PKM yang dilaksanakan, nampak bahwa peserta PKM memahami penyampaian yang telah disampaikan oleh tim terkait dengan pembelajaran bahasa Inggris. PKM yang dilaksanakan menggugah antusias peserta untuk berkreasi dan termotivasi mencoba mengenal dan mempraktikkan bahasa Inggris.

PKM ini diharapkan dapat menambah pengetahuan, keterampilan dan lebih percaya diri. Anak usia dini akan lebih semangat dan termotivasi untuk menirukan dan mempraktekkan bahasa Inggris. Hasil pelatihan ini akan bermanfaat bagi sekolah dan maysrakat. Disamping itu dengan adanya pelatihan ini akan menambah menambah semangat dan ketertarikan anak usia untuk mengenal dan belajar bahasa Inggris.

Hasil kegiatan PKM pelatihan bahasa Inggris bagi anak usia dini secara garis besar mencakup beberapa komponen sebagai berikut:

a. Ketercapaian peserta pelatihan

b. Ketercapaian tujuan pelatihan

c. Ketercapaian target materi yang telah direncanakan

d. Antosias peserta dalam mengikuti rangkaian kegiatan PKM pelatihan bahasa Inggris

e. Kemampuan peserta dalam penguasaan materi

Dalam pelaksanaannya, kegiatan ini diikuti oleh anak usia dini beserta orang tua di daerah terpencil kecamatan Pademawu pamekasan. Dengan demikian dapat dikatakan bahwa target peserta tercapai. Angka tersebut menunjukkan bahwa kegiatan ini dilihat dari jumlah peserta yang mengikuti dapat dikatakan berhasil. 
Ketercapaian tujuan pelatihan bahasa Inggris secara umum tergolong baik. Materi pelatihan yang direncanakan tersampaian kepada peserta pelatihan. Anak usia dini di daerah terpencil Kecamtan Pademawu pamekasan juga memiliki kesempatan untuk mempraktikkan bahasa Inggris secara lisan dan tulis; namun keterbatasan waktu yang disediakan mengakibatkan tidak semua materi tentang routines dan pattern untuk menjadi autonomous learning dapat disampaikan secara detil. Namun dilihat dari hasil latihan dan antusias para peserta maka dapat disimpulkan bahwa tujuan kegiatan ini dapat tercapai.

Ketercapaian target materi pada kegiatan PKM pelatihan bahasa Inggris bagi anak usia dini di daerah terpencil Kecamatan Pademawu tergolong baik karena materi pendampingan telah dapat disampaikan secara keseluruhan dan dapat dipahami dengan baik oleh peserta pelatihan yang dibuktikan dengan pertanyaan yang disampaikan, serta respon yang diberikan baik respon secara verbal maupun non-verbal. Keberhasilan ini selain diukur dari komponen di atas, juga dapat dilihat dari kepuasan peserta setelah mengikuti kegiatan. Kegiatan ini dapat memberikan pengetahuan dan menjadi informasi baru bagi masyarakat terpencil Pademawu untuk membantu masyarakat pesisir memiliki kemampuan berbahasa Inggris. Dengan demikian, hal ini akan merubah perspektif negative masyarakat yan menganggapbahwa bahasa Inggris merupakan bahasa yang sulit dipahami. Selain itu, mereka akan memahmi pentingnya bahasa Inggris di era mellinial.

\section{KESIMPULAN}

Dari hasil dan pelaksanaan kegiatan PKM pelatihan bahasa Inggris bagi anak usia dini di daerah terpencil Kecamatan Pademawu Pamekasan dapat disimpulkan bahwa PKM ini diselenggarakan dengan baik dan berjalan dengan lancar sesuai dengan rencana kegiatan yang telah disusun meskipun belum semua peserta pendampingan menguasai dengan baik materi yang disampaikan. Kegiatan ini mendapat sambutan sangat baik terbukti dengan keaktifan peserta mengikuti pendampingan dengan tidak meninggalkan tempat sebelum waktu pelatihan berakhir. Berdasarkan evaluasi yang telah dilakukan disarankan adanya kegiatan lanjutan yang berupa pelatihan sejenis untuk diselenggarakan secara periodik sehinga dapat mengenalkan bahasa Inggris dan dapat meningkatkan kemampuan masyarakat pesisir dalam berkomunikasi menggunakan bahsa Inggris untuk menghadapi perkembangan pengetahuan di era mellinial.

\section{DAFTAR PUSTAKA}

Amiruddin, M. (2018). The role of social distance between teachers and students in English proficiency. SELL journal, 3 (2), 132-140.

Amiruddin, M. and Suparti, T. (2018). Madurese millennial students' anxiety in learning English, ISLLAC: Journal of intensive studies on language, literature, art, and culture, 2 (2) 34-41.

Fang, X. (2010). The role of input and interaction in second language acquisition. Cross cultural communication. Vol. 6, No. 1, 2010, pp. 11-17

Krashen, S. D. (2009). Principle and Practice in Second Language Acquisition. california: University of Southern California. 